Agrovoc descriptors: foliar application; fertilizer application; plant nutrition;

biofertilizers; basella; stems; dimensions; branching

Agris category code: F61, F62, F04

COBISS code 1.01

\title{
Effect of coir pith based cyanobacterial basal and foliar biofertilizer on Basella rubra $\mathrm{L}$.
}

\author{
P. ABRAHAM CHRISTOPHER ${ }^{1}$, V. VISWAJITH ${ }^{2}$, S. PRABHA ${ }^{3}$, \\ K. SUNDHAR ${ }^{4}$, P. MALLIGA ${ }^{5}$
}

Received: May 25, 2007; accepted: June 20, 2007.

Prispelo 25. maja 2007; sprejeto 20. junija 2007.

\begin{abstract}
The growth promoting effect of basal and foliar application of coir pith based cyanobacterial biofertilizer on Basella rubra L. was determined by analyzing the morphological and biochemical parameters of the control and test plants after treatment. Compared to control plants test plants showed better height, stem circumference, number of branches, number of leaves and number of flowers. Biochemical analysis of test and control plants also revealed similar increase of parameters in test sample. Thus, from our study we recommend cyanobacteria be considered as a serious contender in the field of biofertilizer.
\end{abstract}

Key words: Oscillatoria annae; coir pith; biofertilizer; Basella rubra L.; foliar spray.

\section{IZVLEČEK}

\section{VPLIV BIOGNOJILA IZ OSTANKOV KOKOSOVIH OREHOV IN CIANOBAKTERIJ NA ZDRAVILNO ZELIŠČE Basella rubra L.}

Raziskan je bil vpliv biognojila, dobljenega iz ostankov kokosovih orehov in predelanega $s$ pomočjo cianobakterij na rast rastlin zdravilnega zelišča Basella rubra L. Avtorji so analizirali morfološke in biokemične parameter rastlin tretiranih $z$ gnojilom in kontrolnih rastlin. $S$ preparatom tretirane rastline so bile višje, imele so debelejše steblo, bile so bolj razvejane in imele več listov in cvetov. S cianobakterijami obdelani organski ostanki po predelavi kokosovih orehov bi lahko bili pomembna osnova za pridobivanje biognojil.

Ključne besede: Oscillatoria annae; kokosovi ostanki; biognojilo; Basella rubra L.; foliarno gnojenje.

1,2,3,4 Ph. D. Students, National Facility for Marine Cyanobacteria, Bharathidasan University, Tiruchirappalli-620024, Tamilnadu, India.

5 Reader, National Facility for Marine Cyanobacteria, Bharathidasan University, Tiruchirappalli-620024, Tamilnadu, India. 


\section{INTRODUCTION}

Cyanobacteria play a spectrum of remarkable roles in the field of energy production, biofertilizer, human food, animal feed, polysaccharides, biochemical and pharmaceuticals and in cleaning up of the environment, etc. Cyanobacteria, the oxygen evolving photosynthetic prokaryotes are found in varied aquatic and terrestrial habitats in nature as well as in association with other organisms. They show high flexibility and adapt themselves to varied environments because of their tropic independence to carbon in a number of cases. Cyanobacteria are capable of abating various kinds of pollutants and have advantages as potential biodegradation organism (Malliga and Viswajith, 2005). These organisms degrade various aromatic hydrocarbons and are useful for metal removal from polluted water. As these organisms have simple growth requirements, they could be attractive host for production of valuable organic products.

Coconut (Cocos nucifera L.) is cultivated in tropical countries. The fibrous mesocarp of coir is used to make ropes. The wastes of coir yarn industry get accumulated in large quantities making their disposal difficult, though it is used as soil conditioner. Biofertilizer contains all the nutrients required for the plants and helps to increase the quality of the soil with a natural microorganism environment. Foliar spray could be used in many different growing medium with excellent production results for organic farming, industrial and home application such as gardening. Basella rubra belonging to the family Basellaceae is herbaceous twiners, leaves alternate, simple, penninerved, margin entire, peteolate, estipulate, flowers pink in color. B. rubra stems and leaves are sweet, cooling, emollient, aphrodisiac, laxative, haemostatic, appetizer, sedative, diuretic and tonic. B. rubra has wide distribution in tropical Asia and Africa often cultivated (Matthew, 1983; Sammbamurty, 2006).

\section{MATERIALS AND METHODS}

\subsection{Organism and culture conditions}

Fresh water cyanobacteria belonging to Oscillatoria annae was obtained from the germplasm of National Facility for Marine Cyanobacteria, Bharathidasan University, Tiruchirappalli, Tamil Nadu, India. The culture was maintained in BG11 medium (Rippka et al., 1979) at 1500 lux at $25 \pm 2{ }^{\circ} \mathrm{C}$.

\subsection{Lignocellulosic material}

Coir pith was collected from coir pith industry, Tiruchirappalli, Tamilnadu, India.

\subsection{Experimental condition}

Coir pith was collected from coir pith industry near Tiruchirappalli, Tamilnadu, India. A shallow pit was prepared $6 \mathrm{~m}$ length and $1.5 \mathrm{~m}$ width and a rexin sheet was stretched over the pit. 100 litre of water was added to the pit. The pit was inoculated with $1 \mathrm{~kg}$ of $O$. annae. After 3 days coir pith was added in the ratio 1: 100. Cyanobacteria were allowed to act on the coir pith for 15 days. Coir pith with cyanobacterium was filtered, mixed with soil in 1:1 ratio and used as basal biofertilizer. The supernatant was applied as foliar spray. Totally 14 stem cuts were used for this experiment. Basal and foliar spray was applied on seven cuts which were treated as test. Seven stem cuts without any treatment act as control.

After 40 days of treatment morphological parameters like height of the plant, stem circumference, branching and number of leaves and flowers of $B$. rubra were analysed. 
Biochemical parameters like sugars (Dubois et al., 1956), total phenolics (Swain and Hillis, 1959) nitrate (Wolley et al., 1960) chlorophyll (Arnon, 1949) carotenoid (Goodwin, 1954) and protein (Lowry et al., 1951) were evaluated.

\section{RESULT AND DISCUSSION}

O. annae grew luxuriantly along with coir pith in field condition. During degradation the medium color changed from colorless to brown due to the release of phenolic compounds into the medium. This clearly indicated that the cyanobacterial growth was not inhibited by the presence of the lignin content in coir pith. Combined effect of basal and foliar application of coir pith based cyanobacterial biofertilizer had a positive impact on the growth of $B$. rubra. Morphological observation in control and test plant of $B$. rubra (Table-1) demonstrated increase in stem circumference (104.5 \%), branching (244.36 \%), number of flowers (600 \%), number of leaves (108.9\%) and height of test plants (31.7 \%) over control. Previous studies shows appreciable supporting results. Kumar and Mohan (1997) reported that seaweed liquid fertilizer increased the number of flowers in black gram. This increase in number of leaves was in agreement with our result showing increase in flowers in test sample. Lavanya priya (1997) and Krishna veni (1999) showed a considerable increase in the growth of rice plants with coir pith based cyanobacterial biofertilizer. Spraying of cyanobacterial extract led to increased growth and yield of black gram plant (Ravishankar, 2000). Stephenson (1974) reported a 61\% increase in tomato yield with liquid seaweed extract. Zeenat and Sharma (1990) observed the effect of application cyanobacteria in combination with the chemical fertilizer diammonium phosphate on the growth on yield of tomatoes. The above mentioned results completely supported our study of combining basal and foliar application of coir pith based cyanobacterial biofertilizer.

Table 1: Comparison of morphological parameters of coir pith based cyanobacterial biofertilizer treated and untreated B. rubra.

\begin{tabular}{|c|c|c|c|c|}
\hline $\begin{array}{c}\text { S. } \\
\text { No. }\end{array}$ & Morphological parameters & Control & Test & $\begin{array}{c}\text { \% of increase } \\
\text { over control }\end{array}$ \\
\hline 1. & Height (cm) & $16.1 \pm 0.021$ & $21.2 \pm 0.026$ & 31.7 \\
2. & Stem circumference (cm) & $1.55 \pm 0.013$ & $3.17 \pm 0.018$ & 104.5 \\
3. & Number of branches & $2.57 \pm 0.024$ & $8.85 \pm 0.033$ & 244.36 \\
4. & Number of leaves & $11.2 \pm 0.001$ & $23.4 \pm 0.020$ & 108.9 \\
5. & Number of flowers & $5 \pm 0.031$ & $35 \pm 0.042$ & 600 \\
\hline
\end{tabular}

Values are the mean of three replicates \pm SD. 
Table 2: Comparison of biochemical parameters of coir pith based cyanobacterial biofertilizer treated and untreated B. rubra

\begin{tabular}{|c|c|c|c|c|c|c|c|}
\hline $\begin{array}{c}\text { S. } \\
\text { No }\end{array}$ & Sample & $\begin{array}{c}\text { Sugar } \\
(\mu \mathrm{g} / \mathrm{ml})\end{array}$ & $\begin{array}{c}\text { Phenol } \\
(\mu \mathrm{g} / \mathrm{ml})\end{array}$ & $\begin{array}{c}\text { Nitrate } \\
(\mu \mathrm{g} / \mathrm{ml})\end{array}$ & $\begin{array}{c}\text { Chlorophyll } \\
a(\mu \mathrm{g} / \mathrm{ml})\end{array}$ & $\begin{array}{c}\text { Carotenoid } \\
(\mathrm{mg} / \mathrm{ml})\end{array}$ & $\begin{array}{c}\text { Protein } \\
(\mathrm{mg} / \mathrm{ml})\end{array}$ \\
\hline 1. & Control & $59.3 \pm 0.023$ & $12.6 \pm 0.107$ & $13.7 \pm 0.01$ & $101.0 \pm 4.728$ & $0.07 \pm 0.01$ & $26.0 \pm 0.035$ \\
2. & $\begin{array}{c}\text { Test } \\
\text { \% of } \\
\text { increase } \\
\text { over } \\
\text { control }\end{array}$ & $78.6 \pm 0.035$ & $16.5 \pm 0.042$ & $15.5 \pm 0.125$ & $144.5 \pm 8.922$ & $0.08 \pm 0.012$ & $78.5 \pm 0.04$ \\
\hline
\end{tabular}

Values are the mean of three replicates \pm SD.

The water holding capacity of coir pith is enormous which was a boost to the growth of cyanobacteria. The non-nitrogen fixing cyanobacteria which enriched the phosphorus and potassium content in the soil also played a major role. This may be due to release of growth promoting substance from cyanobacteria Selvarani (1983). Combination of water holding capacity of coir pith and enrichment of soil by nonnitrogen fixing cyanobacteria resulted in enhancement of growth of test plants. This was clearly evident from the biochemical analysis of control and test plants. Biochemical analysis showed and increase in sugar (32.5 \%), phenol (30.9 \%), nitrate (13.1\%), protein (201.9\%), chlorophyll $a$ (43.0\%) and carotenoid (14.2\%) in test plants over control. Thus from our results and earlier reports we conclude that coir pith based cyanobacterial biofertilizer could be an effective alternative or combination for chemical fertilizer.

\section{REFERENCES}

Arnon, D.I. 1949: Copper enzyme in isolated chloroplast. Polyphenol oxidase in Beta vulgaris. Plant Physiol, 24: 1-15.

Dubois, M., Gillis, K.N., Rebers, P.A., Smith, F. 1956: Colorimetric method for determination of sugars and related substances. Anal. Chem, 28: 300-356.

Goodwin, T.W. 1954: Carotenoids. In: K Paech and MV Tracey eds, Handbook of plant analysis. Vol 3: Springer, Berlin, 272-311.

Krishna Zveni, M. 1999: Identification of the compounds responsible for the induction ofsporulation and germination in Anabaena azollae ML2 during the degradation of coir waste and field study of A. azollae and Phormidium valderianum BDU 20041 as coir waste based biofertilizer, M. Sc., dissertation, Bharathidasan University, Tiruchirappalli, Tamilnadu, India.

Kumar, V., Mohan, V.R. 1997: The effect of seaweed liquid fertilizer on black gram. Phykas, 36 (1 \& 2): 43-47. 
Lavanya Priya, S. 1997: Efficacy of coir waste based Anabaena azollae ML2 as abiofertilizer for rice M.Sc., dissertation, Bharathidasan University, Tiruchirappalli, Tamilnadu, India.

Lowry, O.H., Rosebrough, N.J., Farr, A.L., Randall, R.J. 1951: Protein measurement with the Folin phenol reagent. J. Biol. Chem, 193: 265-275.

Malliga, P., Viswajith, V. 2005: Biodegradation of lignin: A search for valuable products. In: Biotechnological Applications in Environmental Management (eds.) R.K. Trivedy and Sadhana Sharma. BS Publications, Hyderabad, India. 232-239 P.

Matthew, K.M. 1983: The flora of the Tamilnadu Carnatic. Diocesan Press, part three, 13271328.

Ravishankar, R. 2000: Effect of cyanobacterial extract on the growth and yield of black gram (Vigna munga Ta Variety). M. Sc., thesis. NFMC, Department of Microbiology, Bharathidasan University, Tiruchirappalli-24.

Rippka, R., Deruelles, J., Waterbury, J.B., Herdman, M.., Stainer, R.Y. 1979: Genetic assignments, strain histories and properties of pure cultures of cyanobacteria J. en. Microbiol, 111: 1-61.

Sammbamurty 2006. Dictionary of Medicinal plants $1^{\text {st }}$ edition, CBS Publishers and Distributors, 253 p.

Selvarani, V.1983. Studies on the influence on nitrogen fixing and non-nitrogen fixing blue green algae on the soil, growth and yield of paddy (Oryza sativa-IR 50). M. Sc., Madurai Kamaraj University, Madurai.

Stephenson, J.W. 1974. The effects of sea weed of extract in the yield of field and glasshouse crops. Abtracts, $8^{\text {th }}$ International symposium, Bangalore. 35 p.

Swain, T., Hillis, W.O. 1959: The phenolic constituents of Prunus domestica. The quantitative estimation of phenolic constitution. J. Sci. Food Agric., 10: 63-68.

Wolley, JT., Hicks, GP., Hageman, RH. 1960. Rapid determination of nitrate in plant material. J. Agric. Food Chem., 8: 481-482.

Zeenat Rizvi, Sharma, V.K. 1990: Synergistic effect of EB and Dap on Tomato yield science and culture, 56: 129-130. 